\title{
The genus Pythiogeton (Pythiogetonaceae) in Brazil
}

\section{Rocha JRS ${ }^{1,2}$, Sousa NDC ${ }^{3}$, Negreiros NC ${ }^{3}$, Santos LA ${ }^{4}$, Pereira AA ${ }^{5}$, Sales PCL and Trindade-Júnior $\mathrm{OC}^{7}$}

${ }^{1}$ Corresponding author: José de Ribamar de Sousa Rocha-e-mail-ribamar10@hotmail.com

${ }^{2}$ Departamento de Biologia, Universidade Federal do Piauí, Campus Ministro Petrônio Portella, Centro de Ciências da Natureza, 64049-550, Teresina, Piauí, Brazil.

${ }^{3}$ Mestrado em Desenvolvimento e Meio Ambiente, Universidade Federal do Piauí, Campus Ministro Petrônio Portella, PRODEMA, TROPEN, 64049-550, Teresina, Piauí, Brazil.

${ }^{4}$ Curso de Graduação em Ciências Biológicas, Universidade Federal do Piauí, Campus Ministro Petrônio Portella, Centro de Ciências da Natureza, 64049-550, Teresina, Piauí, Brazil.

${ }^{5}$ Unidade Escolar Auristela Soares Lima. Avenida Ayrton Senna, 64039-010, Teresina, Piauí, Brazil

${ }^{6}$ Departamento de Biologia, Universidade Federal do Piauí, Campus Senador Helvídio Nunes de Barros, Dep. Biologia, 64600-000, Picos, Piauí, Brazil.

${ }^{7}$ Instituto Federal de Educação Ciência e Tecnologia do Maranhão, Avenida Coronel Stanley Batista, 65365-000, Zé Doca, Maranhão, Brazil.

Rocha JRS, Sousa NDC, Santos LA, Pereira AA, Negreiros NC, Sales PCL, Trindade-Júnior OC 2014 - The genus Pythiogeton (Pythiogetonaceae) in Brazil. Mycosphere 5(5), 623-634, Doi $10.5943 /$ mycosphere $/ 5 / 5 / 3$

\begin{abstract}
Little information can be found on the geographical distribution of the genus Pythiogeton in the world, particularly in South America. In research studies, the technique of multiple baiting has been used for the isolation of these organisms in order to identify the geographical distribution of the genus. One species, Pythiogeton utriforme Minden, has been reported for Argentina, occurring in Buenos Aires (Chascomús), and four for Brazil: P. dichotomum Tokunaga, in Piauí (Parque Nacional de Sete Cidades); P. ramosum Minden, in Rio de Janeiro (Parque Nacional de Itatiaia), Pernambuco (Reserva Florestal Dois Irmãos), São Paulo (Represa de Guarapiranga), Amazonas (Manaus) and Piauí (Parque Nacional de Sete Cidades); P. uniforme Lund, in Piauí (Parque Nacional de Sete Cidades); and P. utriforme Minden, in Piauí (Parque Nacional de Sete Cidades). Herein, thirteen new occurrences of these species are reported for six new localities (five in the state of Piauí and one in Maranhão), increasing the knowledge of the geographical distribution of Pythiogeton in the country. The occurrence of $P$. utriforme with a clearly aplerotic oospore as well as a plerotic oospore, a feature exclusive to Pythiogetonaceae M.W. Dick, is discussed. Internal proliferation of the oogonium, with the formation of a new oogonium with antheridia and oospore was also observed. Descriptions, with special emphasis on morphology, and a brief discussion on the taxonomy and distribution, including drawings and photographs, are presented.
\end{abstract}

Key words - geographic distribution - mycobiota - Piauí - taxonomy - zoosporic organism

\section{Introduction}

A few features of Pythiogeton Minden are similar to those of Pythium Prignsheim. In both genera, the zoospores are formed outside the sporangium in an amorphous mass of protoplasm. 
That said, in Pythium, the formation of the zoospores occurs in a delicate and somewhat spherical vesicle produced at the end of an exit tube whereas, in Pythiogeton, the vesicle is elongate and promptly disappears, leading the protoplasmic mass to cleave into free swimming zoospores. Pythiogeton may also differ from Pythium by the strongly asymmetrical zoosporangium and the long axis usually at a right angle to the axis of the sporangiophore. The genus Pythiogeton is characterized by an extremely thick oospore wall (Sparrow 1960, Jee Ho \& Cho 2000, Huang et al. 2013).

Pythiogeton was transferred from Pythiaceae to a new family, Pythiogetonaceae, with Pythiogeton being the type genus. This family, as well as the genus Pythiogeton, includes the new genus Medusoides H. Voglmayr, with only a single species, Medusoides argyrocodium L. H. Voglmayr (Voglmayr et al. 1999, Dick 2001, Huang et al. 2013). However, after a study of the DNA of the oomycetes by Robideau et al. (2011), Pythiogeton was placed in a phylogenetic tree between the species of Pythium.

Studies of the genus were generally considered difficult due to the reduced ability of the fungus to grow in culture and the absence of sexual structures in some species, and were considered unusual. The initial descriptions of some of the species (Mindem 1916, Ito \& Tokunaga 1935, Batko 1971) were based solely on observations in natural substrates, since pure cultures were not obtained. According to Huang et al. (2013), the species of Pythiogeton are very common, if one observes the correct habitats and employs the appropriate method for isolation of these organisms.

Many species of Pythiogeton are saprophytes occurring in plant debris in rivers, lakes and swamps. Pythiogeton was isolated from leaves of the cattail (Drechsler 1932), rice (Ito \& Tokunaga 1935) and sugar cane (Watanabe 1974). However, these authors did not perform pathogenicity tests and it is not certain whether the Pythiogeton isolates caused plant death or were only saprophytic on the remains of these plants. The first record of pathogenicity of Pythiogeton was P. zeae on corn plants in Korea (Jee Ho \& Cho 2000). The second record was P. zizaniae isolated from bamboo (Zizania latifolia), in Taiwan (Ann Huang \& Wang 2006).

The species of Pythiogeton are facultative anaerobic organisms. Recently, six new species have been described in Taiwan, where it has been observed that species of Pythiogeton prefer to live in anaerobic conditions (Huang et al. 2013).

Continued research on zoosporic organisms, for which Pythiogenton is a representative genus, are necessary to provide a broader understanding of their diversity and geographical distribution. Few experts are available to study large areas in South America, where the genus Pyhtiogeton has received few citations of occurrence (Milanez et al. 2007, Steciow et al. 2012, Forzza et al. 2014).

In Brazil, the species $P$. dichotomum, $P$. uniforme, and $P$. utriforme are known to occur exclusively in the state of Piauí, all in the cerrado biome (Rocha 2002, Milanez et al. 2007). The species $P$. ramosum has the widest geographic distribution in the country, occurring in several types of biomes: in the state of Amazonas, in the Amazon forest (Silva 2002); in the state of Pernambuco, in the Atlantic forest (Cavalcanti 2001); in the state of Piauí, in the cerrado (Rocha 2002); in the state of Rio de Janeiro, in the Atlantic forest (Beneke \& Rogers 1970) and in the state of São Paulo, in the cerrado (Rocha \& Pires-Zottarelli 2002). In Brazil, the only report of species pathogenic to plants was $P$. ramosum in Saccharum officinarum. The state of occurrence and the biome were not specified by the authors (Mendes et al. 1998).

Considering that few studies of zoosporic organisms and fungi are available for all areas of Brazil (Rocha et al. 2001, Rocha 2006, Milanez et al. 2007, Rocha et al. 2010, Forzza et al. 2014) and, particularly, the lack of records on the geographic distribution of Pythiogeton in the country, this study aims to contribute information to broaden the knowledge about the geographical distribution of the genus, with new records of occurrence of the taxon in four new areas in the states of Piauí and Maranhão. Herein, we also discuss the different characteristics of the genus and the existence of plerotic and aplerotic oospores in P. utriforme. 


\section{Material \& Methods}

\section{Areas of research}

The cerrado covers about $33 \%$ of the state of Piauí. The climate is subhumid due to the position of Piauí between the areas of the semiarid northeast and superhumid Amazon. The average annual temperature is $26^{\circ} \mathrm{C}\left(\min .16^{\circ} \mathrm{C}\right.$ and max. $\left.36^{\circ} \mathrm{C}\right)$. The average annual rainfall is $1,500 \mathrm{~mm}$ (min. $500 \mathrm{~mm}$ and max. 3,000 mm), with a short rainy season from December to March. The caatinga represents about $28.4 \%$ of the vegetation of Piauí and encompasses the driest part of northeastern Brazil (7\%). It is dominated by xerophytic and heliophytic vegetation. The climate is hot and dry with 5 to 11 dry months. The average annual rainfall varies between $500 \mathrm{~mm}$ and 700 $\mathrm{mm}$ and the annual average temperature varies between $23^{\circ} \mathrm{C}$ and $27^{\circ} \mathrm{C}$ (MMA/IBAMA 2011).

In the state of Piauí, records of Pythiogeton for the caatinga date to a study carried out in the Parque Nacional Serra das Confusões, from March 2005 to March 2006 (09¹3'33.0'S, $43^{\circ} 27^{\prime} 46.9^{\prime}$ ' $\left.\mathrm{W}\right)$. In the cerrado, the genus was recorded in the Parque Nacional de Sete Cidades, (04 ${ }^{\circ} 15^{\prime} 15^{\prime}$ 'S , 41 ${ }^{\circ} 40$ '40"W), from May 1998 to December 2000 (Rocha 2002); in the municipality of Floriano, in the urban limits of the Parnaíba River, from March 2006 to October 2007 (06 $\left.46^{\circ} 24^{\prime \prime} \mathrm{S}, 43^{\circ} 00^{\prime} 43^{\prime \prime} \mathrm{W}\right)$; in the municipality of Nazária, in the Campo Agrícola de Nazária (5'22'01'S, 42 49'48'W), from March 2007 to March 2008; in the municipality of Teresina $\left(05^{\circ} 05^{\prime} 21^{\prime} \mathrm{S}, 42^{\circ} 48^{\prime} 07^{\prime} \mathrm{W}\right)$, in the Parque Lagoas do Norte, from March 2011 to June 2012, in a community garden, within the urban limits of the Poti River, in August 2013.

In the state of Maranhão, in the cerrado, the genus was recorded in the municipality of Timon, from May 2008 to June 2009 (0504’58.8’S, 4255’16.2’W).

\section{Isolation and culture}

To achieve isolation of zoosporic organisms, soil and water samples were collected and taken to the laboratory. Water samples were placed in $9 \mathrm{~cm}$ diameter Petri dishes containing cellulosic baits (seeds of Sorghum sp., onion bulb cataphylls, corn husks, paper and cellophane). The soil samples were placed in Petri dishes and dissolved in sterilized distilled water before addition of the cellulose baits. Next, the Petri dishes were incubated at room temperature $\left(25^{\circ} \mathrm{C}-32\right.$ ${ }^{\circ} \mathrm{C}$ ) for 5 days. After incubation, the baits were examined under a light microscope (Olympus BX50, Japan) and, once the formation of hyphae was observed, they were transferred to Petri dishes with new baits (Milanez 1989).

Once purified, they were transferred to Petri dishes containing sterilized distilled water and seeds of Sorghum sp. Cultures were maintained at room temperature $\left(25{ }^{\circ} \mathrm{C}-30{ }^{\circ} \mathrm{C}\right)$. The cultures were examined on a weekly basis under a light microscope to verify the production of zoosporangia, oogonia and oospores. After taxonomic identification, selected cultures were deposited in the fungi culture and zoosporic organism collection (abbreviated as ZFBR) of the Federal University of Piauí, Teresina, state of Piauí, Brazil.

\section{Results}

In these studies, the four species of Pythiogeton cited for Brazil (Table 1), P. dichotomum, $P$. ramosum, $P$. uniforme and $P$. utriforme, were recorded in six new localities of occurrence for the country. A total of 45 positive isolations were obtained for the taxa. Only two isolates occurred in the caatinga, which made it impossible to make a more consistent comparison with the 43 isolates obtained in the cerrado.

Table 1 Species of Pythiogeton obtained from samples of water and soil

\begin{tabular}{llllll}
\hline Sample & P. dichotomum & $\boldsymbol{P}$. ramosum & P. uniforme & P. utriforme & Total \\
\hline Water & 08 & 05 & 05 & - & 18 \\
Soil & 07 & 04 & 12 & 04 & 27 \\
Total & 15 & 09 & 17 & 04 & 45 \\
\hline
\end{tabular}


Twenty-seven isolates were obtained from soil samples and 18 from water samples. Apparently, only seeds of Sorghum sp. proved effective in the initial baiting samples of soil and water.

Pythiogeton dichotomum Tokunaga, Transactions of the Sapporo Natural History Society (Japan) 14: 121935

Figs $1 \mathrm{~A}-1 \mathrm{D}$

Mycelium moderately branched, hyphae thin, 2-3 $\mu \mathrm{m}$ diam. zoosporangium terminal on main or lateral hypha, which are unbranched or branched dichotomically once or twice, spherical or ovoid, (20)30(32) $\mu \mathrm{m}$, internally proliferous, thin-walled, up to $1 \mu \mathrm{m}$, with a short exit tube, apical or lateral, 3-5 × 4-25 $\mu \mathrm{m}$. Encysted zoospores, $12 \mu \mathrm{m}$ diam. Sexual structures absent.

Material examined - Brazil, Piauí, Parque Nacional de Sete Cidades, 23 Sep 2000, J. R. S. Rocha, A4/3-S3/3-S4/3-S1/4, ZFBR 74, 04¹5'15"S, 41 40'40"W (Rocha 2002). Parque Nacional Serra das Confusões, 16 Aug 2005, J. R. S. Rocha, A2/2, 09¹3'33.0' 'S, 43'27'46.9' 'W. Floriano, Parnaíba River, 09 Mar 2006, N. C. Negreiros, S3/1-S1/2-S2/2, 0646’24”S, 4300'43”W. Teresina, Parque Lagoas do Norte, 13 May 2012, O. C. Trindade Junior, A1/3-A2/3-A3/1, 0505'21'S, 42 48'07'W. Teresina, Poti River, 14 Aug 2013, N. D. C. Sousa, A4/1. Teresina, Poti

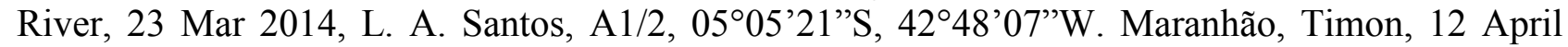
2009, P. C. L. Sales, A3/2, 0504’58.8’S, 4255’16.2”W.

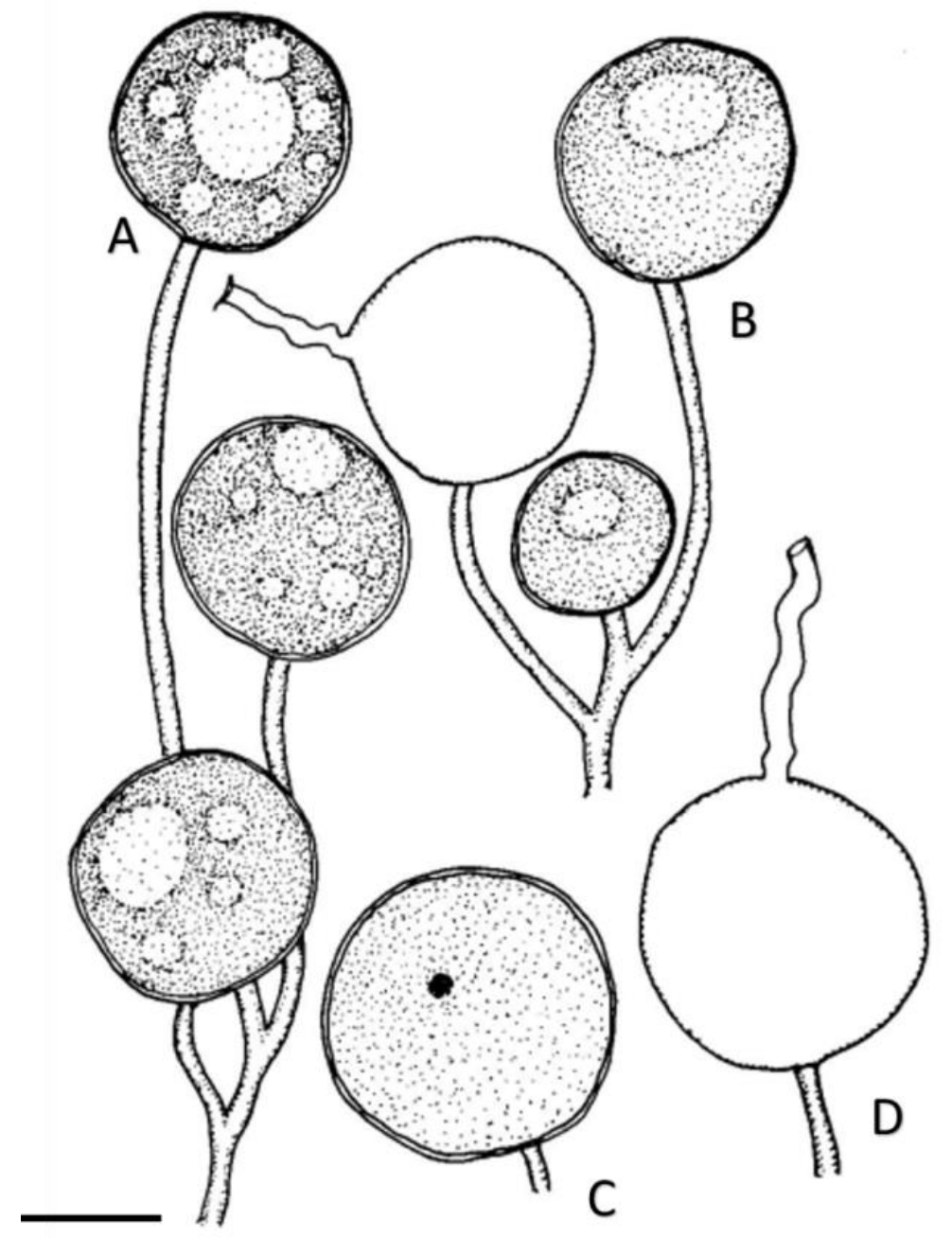

Figs 1 - Pythiogeton dichotomum. A-B Terminal zoosporangium in main or lateral hyphae, which are unbranched or once or twice dichotomously branched, spherical or ovoid. C Zoosporangium before the formation of the exit tube. D Empty zoosporangium with exit tube. - Bar $=15 \mu \mathrm{m}$. 
Notes - The geographical distribution of this species in Brazil is unique to the state of Piauí, in the Parque Nacional de Sete Cidades, where its first record was made (Rocha 2002). New localities of occurrence are cited in Piauí, in the Parque Nacional Serra das Confusões and the municipalities of Floriano and Teresina. The municipality of Timon, in the state of Maranhão, is the first record of the taxon for this state.

Isolates corresponded to the original description of the taxon, presenting the zoosporangia in a characteristic dichotomous position (Figs. 1A-1B) occasionally formed in a long unbranched hypha.

Pythiogeton ramosum Minden. Mykologische untersuchungen und Berichte von Dr. Richard Falck 2(2): 238-243 1916

Figs 2A-2E

Mycelium with thin hyphae, up to $4 \mu \mathrm{m}$ diam., moderately branched. Terminal zoosporangium in supporting hyphae, spherical (15)45(50) $\mu \mathrm{m}$, clearly bursiform (20)48(62) $\times$ (38)58(123) $\mu \mathrm{m}$, with the long axis at right angles to the axis of the supporting hyphae; sometimes internally proliferating, including proliferating twice or more, with the exit tube passing through the walls of the oldest zoosporangium, 4(15)80 $\mu \mathrm{m}$ in length and 4-5 $\mu \mathrm{m}$ in width, straight or sinuous, occasionally helicoid. Encysted zoospores 10-13 $\mu \mathrm{m}$ diam. Sexual structures absent.

Material examined - Brazil, Piauí, Parque Nacional de Sete Cidades, 12 Aug 1999, J. R. S.

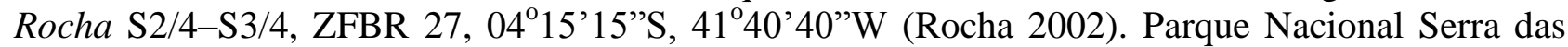
Confusões, 16 Aug 2005, J. R. S. Rocha A4/2, 09¹3'33.0'’S, 4327'46.9'’W. Floriano, Parnaíba River, 25 Aug 2006, N. C. Negreiros A4/2-A1/4- S2/5, 0646’24”S, 4300’43”W. Nazária, Campo Agrícola de Nazária, 15 May 2007, A. A. Pereira S4/2, 5²2'01'S, 4249'48”W. Parque Lagoas do Norte, 14 May 2012, O. C. Trindade Junior A1/3-S2/4, 0505'21'S, 4248'07'W. Maranhão, Timon, 12 Apr 2009 P. C. L. Sales A2/2, 0504'58.8”S, 4255'16.2”W.

Notes - This species has the most well-known geographical distribution in Brazil. The first occurrence was recorded in the state of Rio de Janeiro, in the Parque Nacional de Itatiaia (Beneke \& Rogers 1970). It also occurs in the state of Pernambuco, in Recife, in the Reserva Florestal Dois Irmãos (Cavalcanti 2001). In São Paulo, it occurs in the Guarapiranga reservoir (Rocha \& PiresZottarelli 2002). In the state of Amazonas it occurs in Manaus (Silva 2002) and in the state of Piauí, it occurs in the Parque Nacional de Sete Cidades (Rocha 2002).

Pythiogeton uniforme Lund. Det Kongelige Danske Videnskabernes Selskab Skrifter Naturvides kabelig og Mathematisk Afdeling, 9 Raekke 6(1): 541934

Figs $3 \mathrm{~A}-3 \mathrm{E}$

Mycelium extremely branched, hyphae thin, up to 2-5 $\mu \mathrm{m}$ diam. Terminal zoosporangium, occasionally intercalary, spherical (30)42(50) $\mu \mathrm{m}$, occasionally internally proliferating, with a thin wall which collapses after the release of zoospores. Exit tube 3-4 × 20-500 $\mu \mathrm{m}$, straight or sinuous, formed from different locations around the zoosporangium. Encysted zoospores, $13 \mu \mathrm{m}$ diam. Sexual structures absent.

Material examined - Brazil, Piauí, Parque Nacional de Sete Cidades, 19 Mar 1999, J. R. S. Rocha A4/3, S3/3-S4/3-S1/4, 04 ${ }^{\circ} 15^{\prime} 15^{\prime}$ 'S, 41 40'40"W (Rocha 2002). Floriano, Parnaíba river, 09 Mar, 25 Aug 2006, 14 Jan, 28 Apr, 03 Jul and 15 Out 2007, N. C. Negreiros A1/1-A2/1-S1/1, $\mathrm{S} 3 / 1-\mathrm{S} 4 / 1-\mathrm{S} 1 / 2$, A1/4-A2/4-S3/5, 06 46'24"S, 4300'43"W. Teresina, Parque Lagoas do Norte,

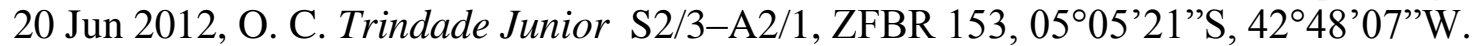

Notes - The geographical distribution in Brazil is unique to the state of Piauí, in the Parque Nacional de Sete Cidades, being the first report for the country (Rocha 2002). In this study, two new localities of occurrence of the taxon are cited: Floriano and Teresina.

The description of the isolates in this study corroborates the original description by Sparrow (1960). In this study, all isolates showed a spherical zoosporangium. According to Huang et al. (2013), the identification of species using only the characteristics of asexual structures often causes doubt regarding the real identity of the taxon, especially if it displays morphological plasticity. In a study carried out by these authors, six species of Pythiogeton produced globose and ovoid 


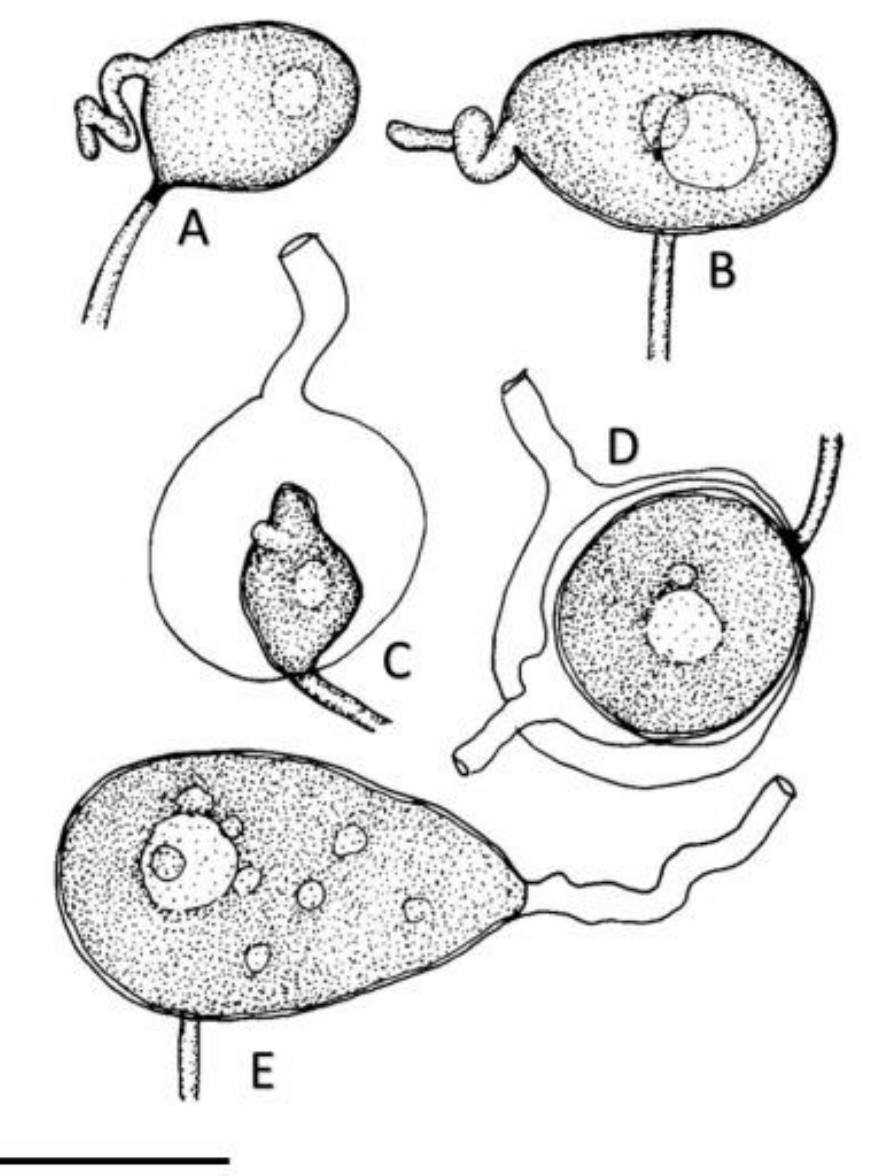

Figs 2 - Pythiogeton ramosum. A-B Terminal zoosporangium in supporting hyphae, bursiform, with sinuous or helicoid exit tube. C-D Spherical zoosporangium proliferating internally, including proliferating two or more times, in $\mathrm{D}$ with exit tube passing through wall of oldest zoosporangia. $\mathrm{E}$ Terminal zoosporangium proliferating internally, with the longest axis at right angle to that of supporting hyphae, with exit tube of oldest zoosporangium empty. - Bar $=30 \mu \mathrm{m}$

zoosporangia, except for $P$. uniforme that had uniformly globose zoosporangia. The zoosporangia in other species are usually globose, but can also be ovoid.

Pythiogeton utriforme Minden. Mykologische untersuchungen und Berichte von Dr. Richard Falck 2(2): 238-243 1916

Figs 4A-4G, Plate 1

Mycelium with thin hyphae, 3-4 $\mu \mathrm{m}$ diam., branched, lateral hyphae thin and more branched than main hyphae. Appressoria formed in lateral hyphae, with intercalary, spherical dilations. Zoosporangium intercalary or terminal, regular bursiform, 30-68 × 50-182 $\mu \mathrm{m}$. Exit tube thin, long. Encysted zoospores 10-13 $\mu \mathrm{m}$. Oogonium terminal, spherical, 33-43 $\mu \mathrm{m}$ diam., thinwalled, formed in thin evanescent hyphae, separated from supporting hypha by septum, sometimes with a short appendix. Rarely proliferating internally. Antheridia single, rarely two, monoclinous, separated by septa of supporting hypha, hemispherical, thin-walled, sometimes with short dorsal appendix, lateral or near the base of the oogonium, forming the fertilization tube. Oospores spherical, 31-40 $\mu \mathrm{m}$ diam., plerotic or aplerotic, very thick and refractive wall, sometimes in concentric layers, 7-10 $\mu \mathrm{m}$, hyaline, content presenting a single globule surrounded by many smaller globules.Germination not observed.

Material examined - Piauí, Parque Nacional de Sete Cidades, 21 Aug 2000, J. R. S. Rocha S4/3-S2/4-S3/4-S8/4, ZFBR 28, 04 ${ }^{\circ} 15^{\prime} 15^{\prime \prime} \mathrm{S}, 41^{\circ} 40^{\prime} 40^{\prime \prime} \mathrm{W}$ (Rocha 2002). Floriano, Parnaíba River, 25 Aug 2006, N. C. Negreiros S1/2-S2/4-S2/5-S3/5, 0646’24’S, 4300'43”W. 


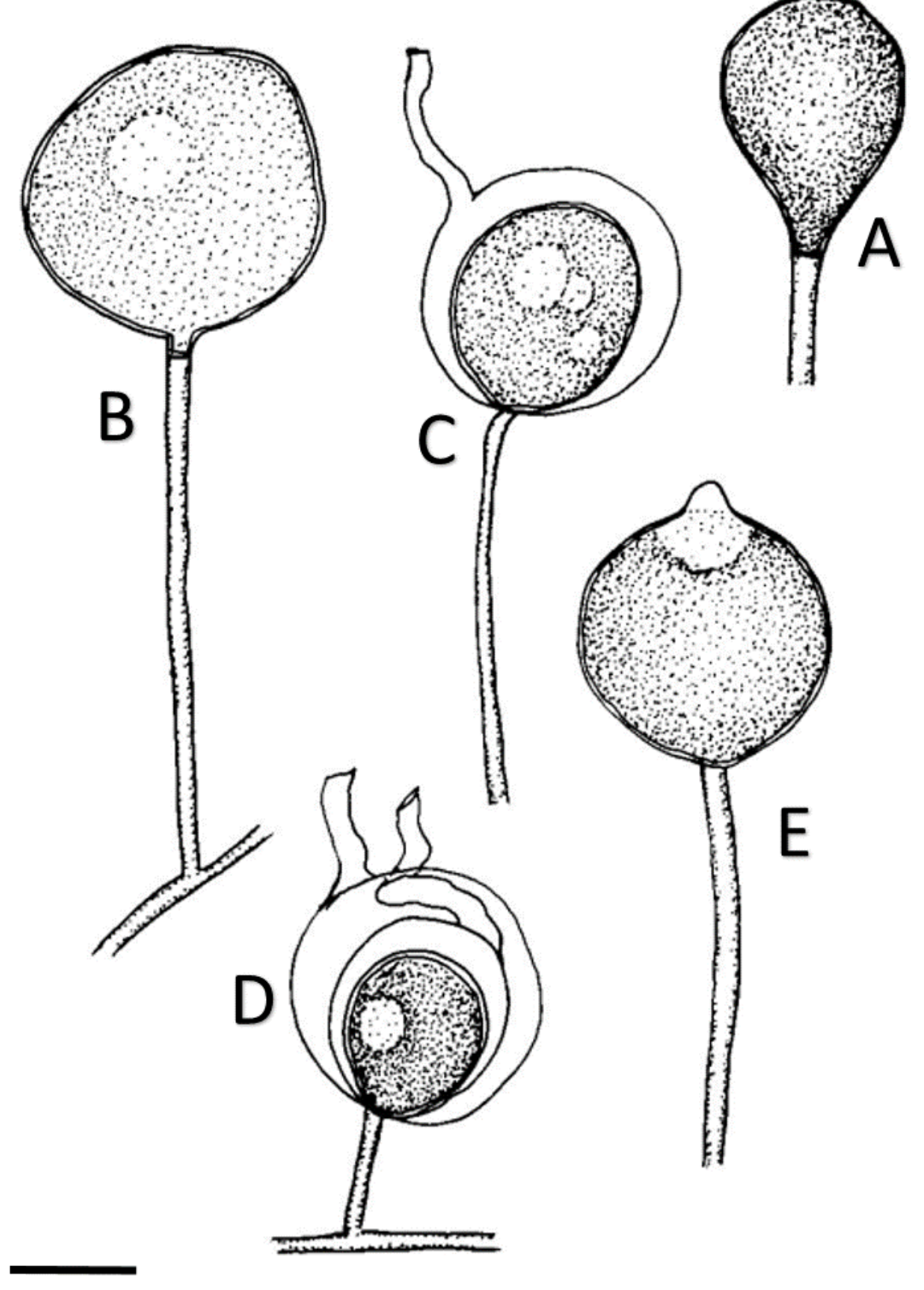

Figs 3 - Pythiogeton uniforme. A Young zoosporangium. B Terminal zoosporangium, spherical, in supporting hyphae. C-D Zoosporangium proliferating internally, including proliferating two or more times, in $\mathrm{D}$ with exit tube passing through wall of oldest zoosporangium. E Zoosporangium initiating formation of the exit tube. - Bar $=20 \mu \mathrm{m}$.

Notes - In Brazil, the only known geographic distribution for the taxon is the state of Piauí, in the Parque Nacional de Sete Cidades which is the first record for the country (Rocha 2002). In this study, another locality of occurrence was included for Piauí, the municipality of Floriano.

In South America, this species also occurs in Argentina, in Chascomús, Buenos Aires (Steciow et al. 2012).

Similarly to Batko (1971), who observed in P. nigrescens oospore wall with three distinct layers, it was possible to identify layers in the oospore of $P$. utriforme. These consisted of a very fine episporium; an intermediary layer, very thick and subdivided exosporium and, in the innermost layer, the endosporium (Plate 1A). Internal proliferation of the oogonium was also observed with formation of new oogonium with antheridia and oospore (Plate 1B). 


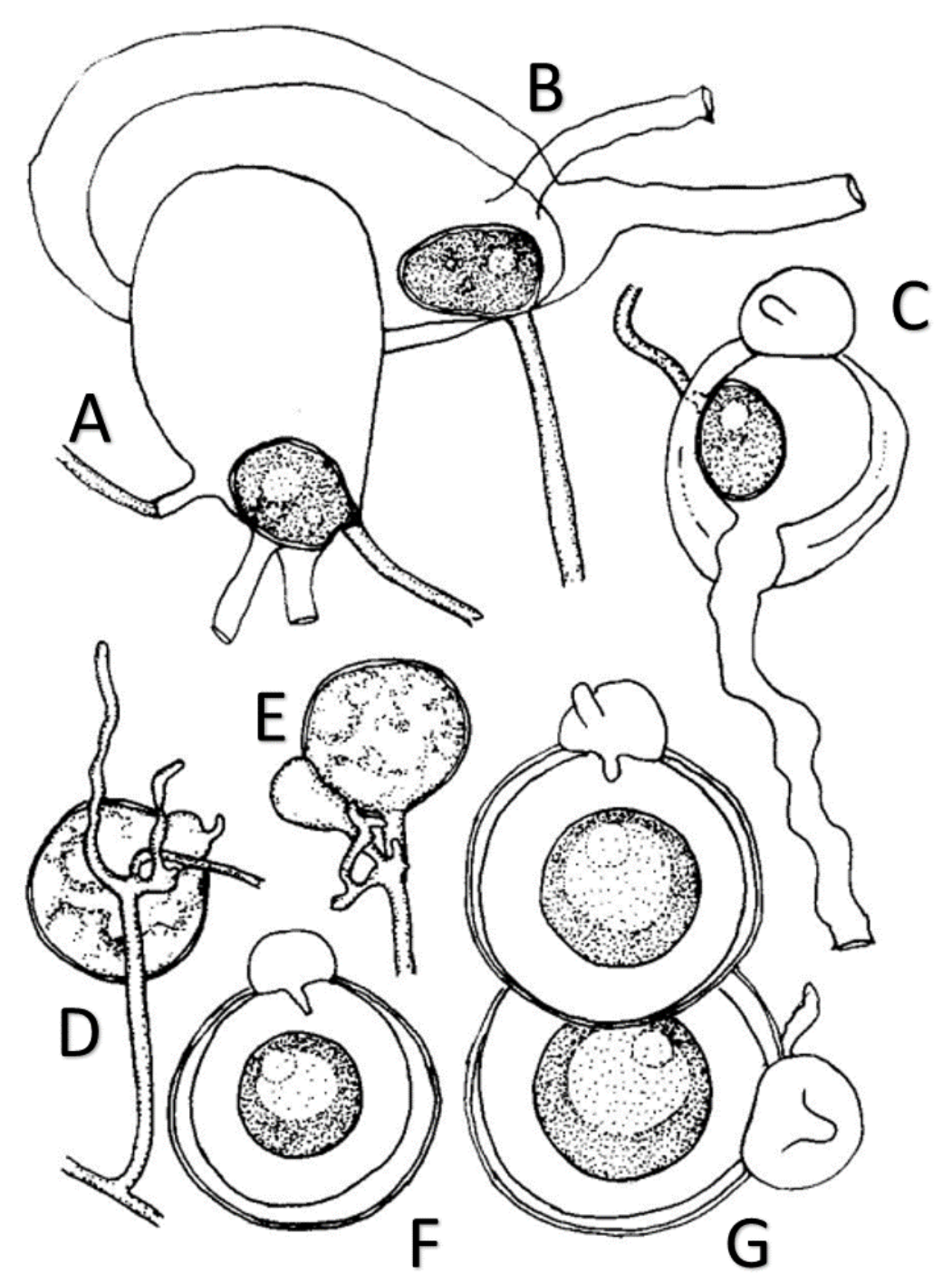

Figs 4 - Pythiogeton utriforme. A-C Terminal zoosporangium, bursiform, internally proliferating, including proliferating two or more times, in $\mathrm{B}-\mathrm{C}$ with exit tube passing through the wall of the oldest zoosporangium. D-E Young oogonium with antheridia. F-G Oogonium spherical, thinwalled, formed in thin evanescent hyphae. Antheridia single, hemispherical, thin-walled with short dorsal appendix. Oospores spherical, aplerotic, very thick-walled, content presenting a single globule surrounded by many other small globules. - Bar $=35 \mu \mathrm{m}$.

\section{General Discussion}

Considering that there is little information on the diversity of fungi and zoosporic organisms in many ecosystems of great diversity, particularly in tropical and subtropical areas (Steciow et al. 2012), the results of this study are important as they extend ourknowledge of the geographical distribution of species of Pythiogeton, which, together with the localities already cited in the specialized literature (Beneke \& Rogers 1970, Cavalcanti 2001, Rocha \& Pires-Zottarelli 2002, Rocha 2002, Silva 2002, Forzza et al. 2014), generate a new map of occurrence for the genus in Brazil (Fig. 5). 

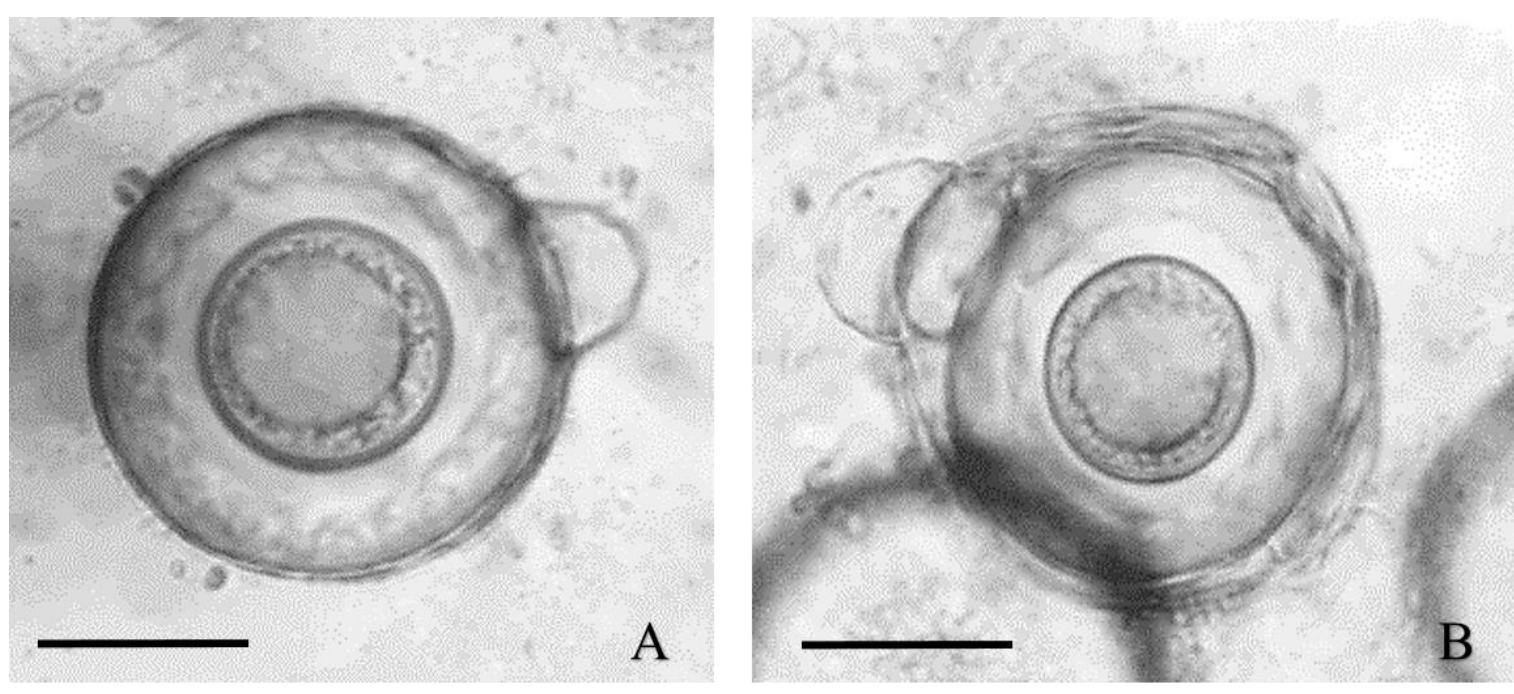

Plate 1 - Pythiogeton utriforme. A Oospore wall with three distinct layers: the very thin external episporium; the very thick exosporium, hyaline and layered; on the inner side it is lined with the thin plasmatic endosporium. Antheridium hemispherical, empty. B Oogonium internally proliferating with oospore and antheridium. - Bars $=15 \mu \mathrm{m}$.

The occurrence of the genus in Brazilin different types of biomes, such as caatinga, cerrado, Atlantic rainforest and Amazon rainforest, indicates that Pythiogeton has a diverse distribution and, possibly, more research might reveal that it occurs in all regions of the country. Studies have reinforced the characteristic that Pythiogeton is unable to grow satisfactorily in synthetic culture. The limited ability of the fungus to grow in pure culture has been observed several times (Ito \& Tokunaga 1935, Batko 1971, Ann et al. 2006, Huang et al. 2013).

The development of the isolates obtained in this study was observed in natural organic substrates. As observed by Huang et al. (2013), species of Pythiogeton are very common if the growing medium used for isolation is suitable and the habitats are correct. The 45 isolates obtained in these studies (Table 1) indicate that at least the researched areas have wide geographic distribution of Pythiogeton.

In a phylogenetic analysis, carried out by Huang et al. (2013), it was observed that all of the isolates of Pythiogeton studied constitute a single clade, within which subgroups can be separated, with each subgroup coinciding with a species of Pythiogeton, established using morphological characteristics. According to these authors, this suggests that the genus Pythiogeton has well defined species and identification based on morphological characteristics is accurate.

Regarding the variation in the shape of the zoosporangia of P. ramosum, Huang et al. (2013) observed bursiform zoosporangia produced in non-sterile water collected in the field, agreeing with the original description of $P$. ramosum. That said, globose, ovoid to ellipsoid, zoosporangia were produced in sterile distilled water, resembling the description of $P$. autossytum. According to these authors, this suggests that $P$. ramosum and $P$. autossytum are the same species but produce different forms of zoosporangia depending on culture conditions. Isolates of $P$. ramosum, in this study, cultured in non-sterile water collected in the field or in sterile distilled water, exhibited the characteristic bursiform zoosporangium and, sometimes, the spherical or irregular sporangium (Figs. 2A-2B).

In the diagnosis of Pythiogetonaceae M.W. Dick (Dick 2001), where the genus Pythiogeton is included, the oospores are exclusively plerotic. In this study, aplerotic oospore was observed in Pythiogeton (Figs. 4F-G, Plate 1A-B). The observation of this characteristic in a member of the Pythiogetonaceae, exposes the need to discuss the limits of the family, especially regarding the position of aplerotic taxa that have been excluded from the family, for example, Achlyopsis entospora De Wild and Pythium gibbosum De Wild (Voglmayr et al. 1999). 
Zebrowska (1976) presented a clear description and illustration of an aplerotic oospore of $P$. autossitum, unlike other researchers (Minden 1916, Sparrow 1936, 1960, Batko 1971) who agreed that the genus is characterized by strictly plerotic oospores. It is evident that further studies on Pythiogeton are necessary to obtain more information about this curious taxon.

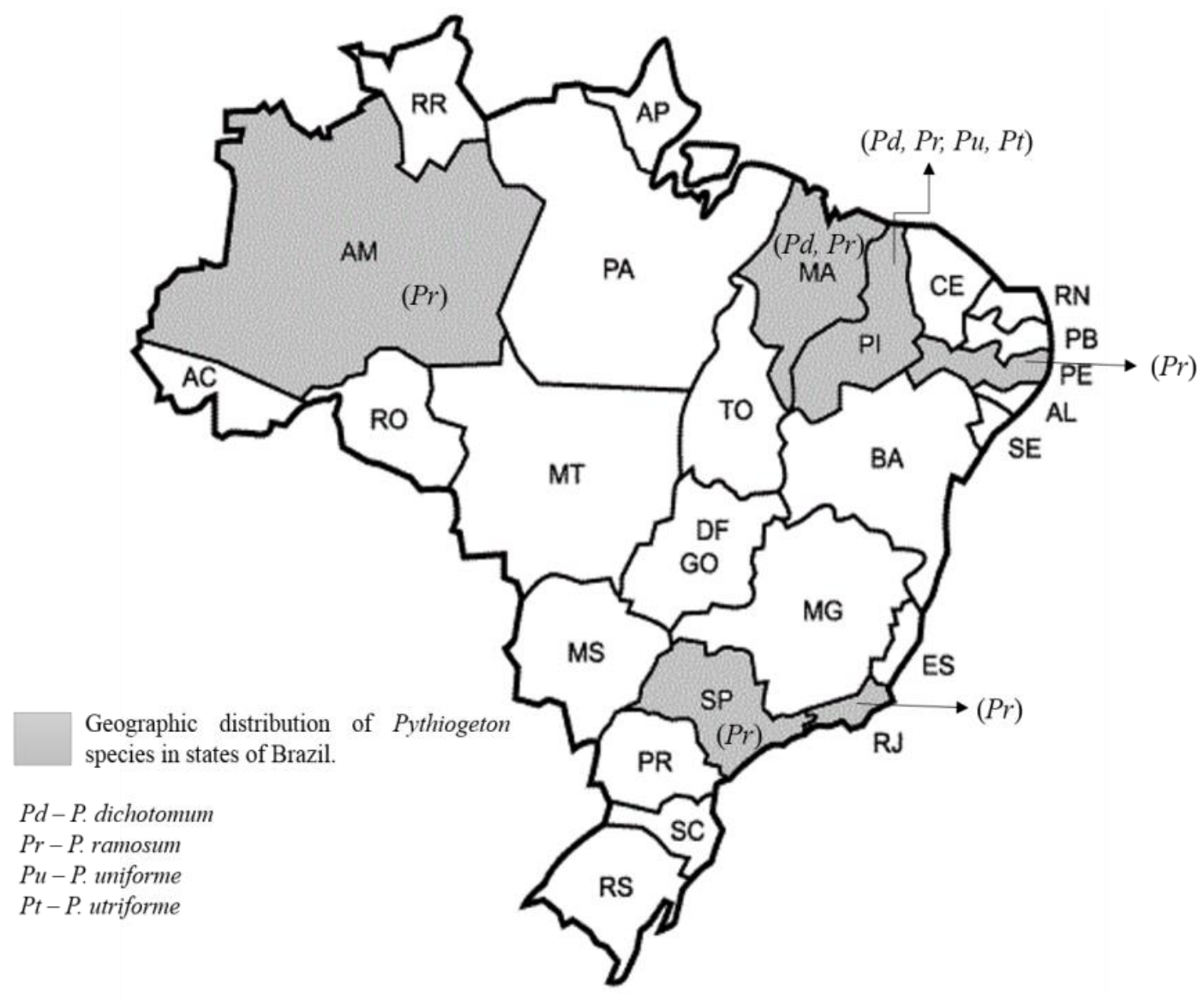

Fig. 5 - Geographical Distribution of Pythiogeton in Brazil. AM: Amazonas, Manaus (Pr) (Silva 2002); MA: Maranhão, Timon $(P d, P r)$ (first record for the state); PI: Piauí, Parque Nacional de Sete Cidades $(P d, P r, P u, P t)$ (Rocha 2002), Teresina (Pd, Pr; Pu) (new records), Nazária $(P r)$ (new record) and Floriano $(P d, P r ; P u, P t)$ (new records); PE: Pernambuco, Recife, Reserva Florestal Dois Irmãos (Pr) (Cavalcanti 2001); RJ: Rio de Janeiro, Parque Nacional de Itatiaia, $(P r)$ (Beneke \& Rogers 1970); SP: São Paulo, São Paulo, Represa do Guarapiranga (Pr) (Rocha \& PiresZottarelli 2002).

\section{References}

Ann PJ, Huang JH, Wang IT, Ko WH. 2006 - Pythiogeton zizaniae, a new species causing basal stalk rot of water bamboo in Taiwan. Mycologia 98, 116-120.

Batko A, 1971 - A new species of Pythiogeton showing Achlya like diplanetism. Acta Mycologica 7, 241-249.

Beneke ES, Rogers L. 1970 - Aquatic fungi of Parque Nacional de Itatiaia in the State of Rio de janeiro. Rickia 5, 51-64.

Cavalcanti MS. 2001 - Fungos isolados da água e do solo das margens dos açudes do Prata e do Meio, na Reserva Florestal de Dois Irmãos, Recife - PE. Tese de Doutorado, Universidade de São Paulo, São Paulo. 316p.

Dick MW. 2001 - Straminipilous Fungi: Systematics of the Peronosporomycetes Including Accounts of the Marine Straminipilous Protists, the Plasmodiophorids and Similar Organisms. Kluwer Academic Publishers, Netherlands. 
Drechsler C. 1932 - A specie of Pyhtiogeton isolated from decaying leaf-sheaths of the common cat-tail. J Wash Acad Sci 22, 421-449.

Forzza RC, Leitman PM, Costa AF, Carvalho Jr AA, Peixoto AL, Walter BMT, Bicudo C, Zappi D, Costa DP, Lleras E, Martinelli G, Lima HC, Prado J, Stehmann JR, Baumgratz JFA,; Pirani JR, Sylvestre L, Maia LC, Lohmann LG, Queiroz LP, Silveira M, Coelho MN, Mamede MC, Bastos MNC, Morim MP, Barbosa MR, Menezes M, Hopkins M, Secco R, Cavalcanti TB, Souza VC. 2013 - Lista de espécies da flora do Brasil. Jardim Botânico do Rio de Janeiro. http://floradobrasil.jbrj. gov.br/2014/ (acessede 14 March 2014)

Huang JH, Chen CY, Lin YS, Ann PJ, Huang HC, Chung WH. 2013 - Six new species of Pythiogeton in Taiwan, with an account of the molecular phylogeny of the genus. Mycoscience $54,130-147$.

MMA/IBAMA. 2011 - Ministério do Meio Ambiente, Instituto Brasileiro do Meio Ambiente e dos Recursos Naturais e Renováveis. Monitoramento do desmatamento nos biomas brasileiros por satellite. Acordo de cooperação MMA e IBAMA, Brasília, DF.

Ito S, Tokunaga Y. 1935 - Notae mycologicae Asiae orientalis I. Transactions of the Sapporo Natural History Society 14, 1-33.

Jee HJ, Ho HH, Cho WD. 2000 - Pythiogeton zeae sp. nov. causing root and basal stalk rot of corn in Korea. Mycologia 92, 522-527.

Mendes MAS, Silva VL, Dianese JC, Ferreira MASV, Santos CEN, Gomes NE, Urben AF. (eds.). 1998 - Fungos em plantas no Brasil. Brasília, Embrapa- SPI/Embrapa-Cenargen. 569p.

Milanez AI. 1989 - Fungos de águas continentais. In: Fidalgo, O. \& Bononi, V. L. (Coord.). Técnicas de coleta, preservação e herborização de material botânico. Série Documentos. São Paulo. Instituto de Botânica.

Milanez ML, Pires-Zottarelli CLA, Gomes AL. 2007 - Brazilian zoosporic fungi. São Paulo: WinnerGraph.

Minden M. 1916 - Beitrage zur biologie und systematic einheimscher submerser Phycomyceten. Mykologische Untersuchungen und Berichte von Dr Richard Falck 1, 146-255.

Robideau GP, De Cock AWAM, Coffey MD, Voglmayr H, Brouwer H, Bala K, Chitty DW, Desaulniers N, Eggertson QA, Gachon CM, Hu CH, Kupper FC, Rintoul TL, Sarhan E, Verstappen EC, Zhang Y, Bonants PJ, Ristaino JB, Levesque AC. 2011 - DNA barcoding of oomycetes with cytochrome c oxidase subunit I and internal transcribed spacer. Molecular Ecology Resources 11, 1002-1011.

Rocha JRS, Milanez AI, Pires-Zottarelli CLA. 2001 - O gênero Pythium (Oomycota) em área de cerrado no Parque Nacional de Sete Cidades, Piauí, Brasil. Hoehnea 28(3), 209-230.

Rocha, JRS. 2002 - Fungos zoospóricos em áreas de cerrado no "Parque Nacional de Sete Cidades", Piauí, Brasil. Tese de Doutorado, Instituto de Biociências, USP, São Paulo, SP. 266p.

Rocha JRS. 2006 - Filos Chytridiomycota e Oomycota. PP. 75-95. In: A. M. Giullietti (Ed.). Diversidade e caracterização dos fungos do semi-arido. Recife. Associação Plantas do Nordeste.

Rocha JRS, Rodrigues EP, Silva HSVP, Sousa LMA, Barros BSV. 2010 - Distribuição geográfica de Aphanodictyon papillatum Huneycutt ex Dick (Saprolegniales) no Brasil. Acta Botanica Malacitana 35, 171-176.

Rocha M, Pires-Zottarelli CLA. 2002 - Chytridiomycota e oomycota da Represa do Guarapiranga, São Paulo, SP. Acta Botanica Brasilica 16, 287-309.

Shen SC, Siang WN. 1948 - Studies in the aquatic Phycomycetes of China. Sci. Rep Nat Tsing Hua Univ, Ser B 3, 179-206.

Silva MIL. 2002 - Micobiota de água e de solo das margens de igarapés situados na area de mata do campus da Universidade do Amazonas, Manaus, AM. Doctor Thesis, Instituto de Biociências, USP, São Paulo.176p.

Sparrow Jr FK. 1932 - Observations of the aquatic fungi of Cold Spring Harbor. Mycologia 24, 268-303. 
Sparrow Jr FK. 1960 - Aquatic Phycomycetes. Second Revised Edition. University of Michigan Press, Ann Arbor.

Steciow MM. 1996 - Hongos acuáticos zoosporicos (oomycetes, Mastigomycotina) en laguna Vitel y tributaries (Buenos Aires, Argentina). Boletin de la Sociedad Argentina de Botanica 32, 67-73.

Steciow MM, Milanez AI, Pires-Zottarelli CLA, Marano AV, Lecther PM, Vélez CG. 2012 Zoosporic true fungi, heterotrophic straminipiles and plasmodiophorids status of knowledge in South America. Darwiniana, 5(1). http://www.scielo.org.ar/scielo.php?pid=S001167932012000100002\&script=sci_arttext (acessed 13 August 2013)

Voglmayr H, Bonner LJ, Dick MW. 1999 - Taxonomy and oogonial ultrastructure of a new aeroaquatic peronosporomycete, Medusoides gen. nov. (Pythiogetonaceae fam. nov.). Mycological Research 103, 591-606.

Watanabe T. 1974 - Fungi isolated from the underground parts of sugar cane in relationship to the poor rationing in Taiwan. (2) Pythium and Pythiogeton. Transactions of the Mycological Society of Japan $15,343-357$.

Zebrowska E. 1976 - Nikoflora kilku zbiornikow wodnych Puszczy Kampinoskiej. Acta Mycologica 12, 77-89. 